\title{
An Analytical Study on the Impact of Recent Oil Price Plunge on Highly Oil Dependent Economies and Oil Exporting Countries
}

\author{
Indrani Hazarika
}

\begin{abstract}
Oil and gas industries is one of the largest industries worldwide. From the second half of 2014, international oil prices slumped, generating a heavy macroeconomic shock on net oil exporters, particularly those countries whose GDP and exports are dominated by oil. The present study has been undertaken to analyze the impact of the recent oil price crash on five oil dependent economies, biggest oil exporting countries and five countries most affected by the recent oil price crash. Statistically significant results were observed only in few oil dependent economies when macroeconomic factors were regressed against crude oil prices. Falling crude oil prices can impact decision making in monetary, fiscal and structural policies. However, the effects of a decline in the price of oil vary across economies, largely as a result of differences in the patterns of trade in oil-related products and in the oil intensity of production. For net importers of oil, which account for a significantly larger share of global GDP than net exporters, a falling oil price is expected to lead to an increase in the terms of trade, an increase in the purchasing power of households and lower input costs for businesses. For net exporters of oil, the terms of trade are likely to decline, although this will be offset to a greater or lesser degree by the effects on household purchasing power and lower input costs for businesses.
\end{abstract}

Index Terms-Crude oil price, GDP, macroeconomic factors, oil price crash.

\section{INTRODUCTION}

Oil and gas industries is one of the largest industries worldwide and is involved in the exploration, extraction, refining, transport and marketing of oil and gas products. Many industries are heavily dependent on oil and gas products in the form of energy, fuel or raw materials for chemical products. From the second half of 2014, international oil prices slumped and the sharp decline in oil prices generated a heavy macroeconomic shock on net oil exporters, especially those countries whose GDP (Gross Domestic Product) and exports are dominated by oil. There are four groups of oil producers. The first group includes countries with the greatest dependence on oil rents (over 30 percent of GDP): Kuwait, Libya, Saudi Arabia, Iraq, Oman and Azerbaijan. In the second group, the share of oil rents in GDP varies between 20 and 30 percent: Algeria, Brunei Darussalam, Iran, Kazakhstan, Qatar, UAE and Venezuela. The third group is characterized by a moderate dependence

Manuscript received on March 3, 2016; revised on August 3, 2016.

Indrani Hazarika is with the Dubai Women's College, UAE (e-mail: ihazarika@hct.ac.ae). (between 10 and 20 percent of GDP) and includes Bahrain, Ecuador, Nigeria and Russia. The fourth group represents countries with an oil rent share below 10 percent of GDP and includes Bolivia, Canada, Colombia, Indonesia, Malaysia, Norway and Sudan.

The present study has been undertaken to analyze the impact of the recent oil price crash on five oil dependent economies, biggest oil exporting countries and five countries most affected by the recent oil price crash.

\section{A. Why Have Oil Prices Fallen?}

Commodity prices, like most others, are determined by two factors: supply and demand (Fig. 1 History of Crude Oil Prices). The recent plunge in oil prices has been led by a rise in supply, as US production has picked up with the advent of shale gas investment on a large scale. Meanwhile, crude demand in China has been lowered, the world's second largest economy, moves away from energy- intensive industrial growth, towards a more consumption-led model of development. The causes of sharp decline can be attributed to recent developments in global oil markets that have occurred against a long term trend of greater than anticipated supply and less than anticipated demand, slow economic growth in 2015, US dollar appreciation, changes in OPEC (Organization of the Petroleum Exporting Countries) objectives, geo political situation in Libya and Iraq, the two main oil producers that has not affected their output. America has become the world's largest oil producer [1]. Though it does not export crude oil, it now imports much less, creating a lot of spare supply. United States domestic production has nearly doubled over the last several years and Saudi, Nigerian and Algerian oil that once was sold in the United States is suddenly competing for Asian markets, and the producers are forced to drop prices. As it is possible to store oil, changes in oil inventories are possibly a third driver behind oil price fluctuations. Canadian and Iraqi oil production and exports are rising year after year. The drop in production is not happening fast enough, especially with output from deep waters off the Gulf of Mexico and Canada. On the demand side, the economies of Europe and developing countries are weak and vehicles are becoming more energy-efficient. So demand for fuel is lagging a bit. Secondly world oil production has generally increased since 1996 to more than 80 million barrels a day, from 63 million but demand has not increased proportionately. Fig. 2 shows the daily demand for crude oil worldwide from 2006 to 2015.

\section{B. Impact of Falling Oil Prices}

Earnings are down for companies that have made record profits in recent years, leading them to decommission 
roughly two-thirds of their rigs and sharply cut investments in exploration and production. An estimated 250,000 oil workers have lost their jobs and manufacturing of production and drilling equipment has fallen sharply. Oil companies have announced cuts to their payrolls to save cash, slashing dividends and selling assets as they reported net losses. Airlines seem to be more interested in adding flights than reducing ticket prices in response to lower oil prices, perhaps because additional planes are already available. Their intent is to increase profits, through an increase in ticket sales, not to give consumers the benefit of lower prices [2]. Seven unexpected consequences of falling oil prices include [3].

Increased consumer spending: The less we spend on transport the more we have in our pockets for buying other things, which should boost consumer spending and strengthen economies.

Extra cash in some developing countries: Countries that import oil will see direct economic benefits in terms of their balance of payments.

Welfare cuts in some states: Big oil exporting countries, such as Russia and Venezuela, rely on what they earn from oil to support their social welfare systems. There is concern that healthcare, education and social assistance could be affected.

Layoffs in the energy sector: Falling crude prices means operations are making less money and companies will want to reduce costs and may lead to massive redundancy plans.

Less investment in clean energy: As oil prices drop, many people see less of a need to seek alternative energy sources like wind, solar or electric power.

More traffic on the roads: Cheaper prices mean that people are more inclined to fill up and take to the road more often, meaning more congestion and of course more pollution. There is also the likelihood of more traffic accidents and hospitalizations.

A change in geopolitics: As the price of crude oil falls, countries that were once enormously influential because of their oil wealth may find themselves having to reassess their foreign relations.

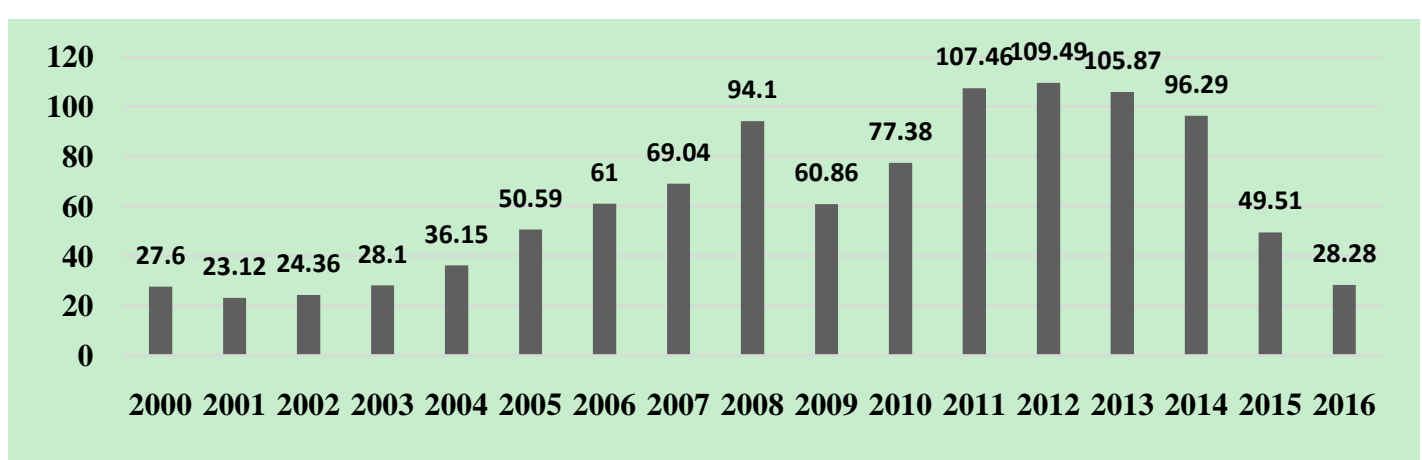

Fig. 1. Average Prices for OPEC crude oil in USD per barrel from 2000 to 2016.

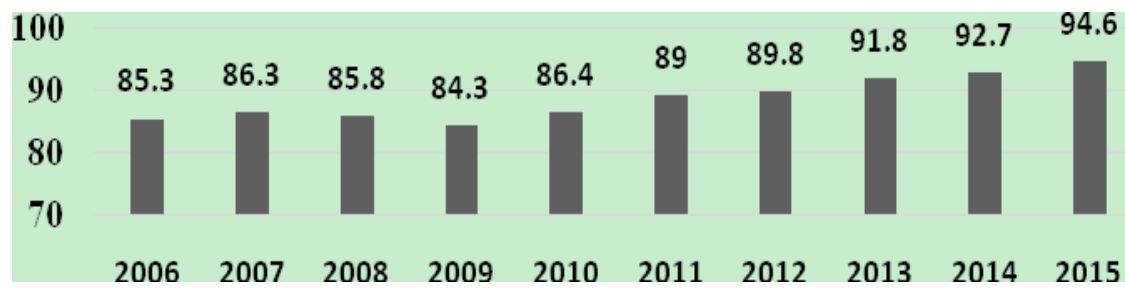

Fig. 2. Daily demand for crude oil worldwide in million barrels per day from 2006 to 2015 .

\section{LITERATURE REVIEW}

Economic weakness in Europe and Japan have certainly contributed to the falling price of oil and have underscored fears about global growth. The technology of hydraulic fracturing or "fracking" and other technologies that allow us to access previously inaccessible energy reserves has enabled the development of significant new supplies in North America. According to the U.S.Energy Information Administration (EIA), U.S production has risen roughly $45 \%$ over the last four years while Canada now produces approximately $25 \%$ more than it did four years ago. Together, Canada and the United States produce some five million more barrels of oil each day than they did in 2010.The price of oil has been dropping so fast because United States domestic production has nearly doubled over the last several years. Saudi, Nigerian and Algerian oil that once was sold in the United States is suddenly competing for Asian markets, and the producers are forced to drop prices. Canadian and Iraqi oil production and exports are rising year after year. Oil-producing countries like Venezuela, Nigeria, Ecuador, Brazil and Russia are suffering economic and perhaps even political turbulence [4]. Global oil prices may stay low for the next 10 or 20 years, according to Stanford economist Frank Wolak. In his analysis, Wolak cited seven factors driving a long-term oil price decline: North American Shale Oil Production, declining role of OPEC, standardization of oil well drilling, cost difference between natural gas and oil, shale oil and technology exports and flattening of oil supply curve [5]. Saudi Arabia, Venezuela, Qatar, and Russia reached a historic agreement to cap oil production at mid-January 2016. The pact - the first between OPEC and a non-OPEC member in 15 years - aims to halt the precipitous fall in oil prices that has wreaked havoc around the world [6] 
Impact of Recent Oil Price Crash on Oil Economies (Refer to Fig. 3)

2.1.1 Venezuela: Oil accounts for $96 \%$ of Venezuela's exports. $40 \%$ of government revenues and hard currency reserves depend on oil, and with the price of oil 50 percent down, the country is close to a default as the economy shrank by 5.7 percent in 2015 .

2.1.2 Nigeria: The country's budget breakeven price of oil for 2015 is $\$ 122$, according to Deutsche Bank estimates. Moreover, oil exports constitute more than 70 percent of Nigeria's budget income and 90 percent of its foreign exchange. The Nigerian naira has lost the fifth of its value against the US dollar since June 2014 due to the recent oil price crash.

2.1.3 Iraq: Iraq is particularly affected by the oil prices slump, as the country's finances depend exclusively on oil exports, and oil price volatility strongly affects its economy. At the moment, Iraq is effectively increasing its oil production in order to offset the slump in oil prices.

2.1.4 Russia: Falling oil prices have exposed Russia's continued dependence on energy exports. The Russian 2015-2017 budget draft is based on the $\$ 100$ per barrel price.
The inflation is currently at 17 percent and the rouble slumped by 44 percent in the past 12 months.

2.1.5 Iran: Iran has been a major victim of both the ban on oil exports imposed by the international community and the falling oil prices. The sudden drop in oil prices is threatening to plunge the country into a full-blown recession.

2.1.6 Libya: Libya is a single-industry economy, with the energy sector accounting for $65 \%$ of GDP and $95 \%$ of government revenue. Libya produces 1.7 million barrels of oil per day, while exporting 1.2 million barrels daily.

2.1.7 Angola: Angola produces 1.9 million barrels of oil daily, and exports 1.8 million barrels, placing them seventh on the world's list of exporters. The dominant oil industry accounts for more than 50\% of Angolan GDP and more than $70 \%$ of government revenue.

2.1.8 Kuwait: Like most of the other countries on this list, Kuwait relies on oil for more than half of its GDP and almost all of its export revenues.

2.1.9 Brazil: Low oil prices will add pressure to Brazil's economy because higher prices are needed to stimulate investment in the country's deep-water offshore oil fields that will contribute to economic growth.

Oil dependent Economies

\begin{tabular}{|l|l|c|}
\hline Five most oil dependent economies & World's biggest Oil Exporters & $\begin{array}{c}\text { Five countries most affected by the oil } \\
\text { price crash }\end{array}$ \\
\hline Venezuela & Venezuela & Venezuela \\
\hline Libya & Nigeria & Nigeria \\
\hline Russia & Russia & Iraq \\
\hline Angola & Brazil & Russia \\
\hline Kuwait & & Iran \\
\hline
\end{tabular}

\begin{tabular}{|c|c|c|c|c|c|c|c|c|c|}
\hline YEAR & \multicolumn{9}{|c|}{ OIL ECONOMIES } \\
\hline & Venezuela & Libya & Russia & Angola & Kuwait & Nigeria & Brazil & Iran & Iraq \\
\hline 2010 & $(1.49)$ & 5.43 & 4.5 & 3.41 & $(2.37)$ & 9.97 & 7.57 & 6.58 & 6.4 \\
\hline 2011 & 4.18 & 4.23 & 4.3 & 3.92 & 10.61 & 4.89 & 3.92 & 3.75 & 7.55 \\
\hline 2012 & 5.63 & 3.43 & 3.4 & 5.16 & 7.67 & 4.28 & 1.76 & $(6.61)$ & 13.94 \\
\hline 2013 & 1.34 & 3.31 & 1.3 & 6.8 & 0.82 & 5.39 & 2.74 & $(1.91$ & 6.57 \\
\hline 2014 & (4) & 3.43 & 0.6 & 4.8 & 0.14 & 6.31 & 0.15 & 4.34 & $(2.12)$ \\
\hline 2015 & (10) & 3.12 & 3.83 & 3.49 & 1.17 & 3.96 & $(3.03)$ & 0.83 & 0.03 \\
\hline
\end{tabular}

Fig. 3. GDP growth rate in the oil economies from 2010 to 2015 in percentage.

\section{RESEARCH METHODOLOGY}

The study is based on the impact of fluctuating oil prices on the macro economic factors of five oil dependent economies, world's biggest oil exporters and five countries most affected by the oil price crash from 2010 to 2015 considering post global crisis period and recent oil price crash.

\section{A. Research Questions}

The research question addressed in the present study is whether fluctuating oil prices impact the macro economic factors like GDP, GDP growth rate and inflation.

\section{B. Data Analysis}

The financial data have been analyzed with the help of Data Analysis in Excel using Significance F and R square in simple regression analysis where the independent variable is the crude oil price and macro-economic factors are dependent variables. The following model is repeatedly used for the study to establish the relation between the dependent variables and single independent variable for five observations in the oil dependent economies. Equation: $\mathrm{Y}=\beta 0+\beta 1 \mathrm{X} 1+\mu$ where $\beta 0$ is the intercept and independent variable $X$ is the crude oil price and dependent variable $\mathrm{Y}$ represents the macro economic factors and $\mu$ represent the error term.

\section{Regression Output}

Crude oil price in USD per barrel from 2010 to 2015 has been regressed against the GDP of the oil dependent nations mentioned in (Fig. 3). The results were statistically significant for Russia, Brazil and Kuwait as the R squared and Significant $F$ was 0.95 and 0.0007, 0.90 and 0.003 and 
0.66 and 0.04 respectively for Russia, Brazil and Kuwait. R squared implies the percentage of GDP dependent on crude oil prices. Statistically significant results were also seen in case of Venezuela, Russia and Brazil when crude oil prices were regressed against inflation. $\mathrm{R}$ Squared and significant $\mathrm{F}$ was 0.99 and $0.0003,0.92$ and 0.008 and 0.89 and 0.01 in respect of Venezuela, Russia and Brazil.

\section{Finding}

Statistically significant results were observed only in few oil dependent economies when macroeconomic factors were regressed against crude oil prices. Falling crude oil prices can impact decision making in monetary, fiscal and structural policies. However, the impetus to shift these policies depends on whether a country is an oil importer or exporter [7]. According to estimates of the Saudi Arabian Monetary Institution, the total value of Saudi exports of goods during 2015 was estimated at 767.2 billion riyals, a decrease of $40.2 \%$, compared to the previous fiscal year. The trade balance for 2015 achieved a surplus of 235.3 billion riyals, a decrease of $65.9 \%$ compared to the previous year, as a result of the significant decline in oil exports despite the drop in imports. At the same time, the estimates of the current account deficit of the balance of payments reached 155 billion riyals in the year 2015, compared to a surplus of 288.4 billion riyals in 2014 [8]. The Soviet Union was dependent on oil for its export revenue. Many oil-exporting countries are at risk of collapse if oil prices stay very low very long. Venezuela is a clear risk, with its big debt problem. Nigeria's economy is also highly affected [9]. Recent estimates from the International Monetary Fund suggest that the increase in global growth from the recent fall is likely to be substantial [10].

\section{CONCLUSION}

Falling oil prices tend to lead to a lower price for growing food and a lower price for making most goods. The net result can be deflation. A fall in the oil price as a result of an increase in oil supply is expected to increase global growth overall, as would be expected for any positive supply shock. However, the effects of a decline in the price of oil vary across economies, largely as a result of differences in the patterns of trade in oil-related products and in the oil intensity of production. For net importers of oil, which account for a significantly larger share of global GDP than net exporters, a falling oil price is expected to lead to an increase in the terms of trade, an increase in the purchasing power of households and lower input costs for businesses [11]. For net exporters of oil, the terms of trade are likely to decline, although this will be offset to a greater or lesser degree by the effects on household purchasing power and lower input costs for businesses.

\section{REFERENCES}

[1] J. Baffles, A. Kose, F. Ohnsorge, and M. Stocker, "Understanding the plunge in oil prices: Sources/implications," Global Economic Prospects, pp. 155-168, 2015.

[2] J. Bachman, "How cheap oil could become a real problem for airlines," October 2014.

[3] S. Kearney, "Seven unexpected consequences of falling oil prices," Euro News, January 2015.

[4] C. Krauss. (February 2016). [Online]. Available: http://www.nytimes.com/interactive/2016/business/energyenvironmen t/oil-prices

[5] C. B. Parker, "The global oil price drop may last for the next couple decades," Stanford News, 2015.

[6] 3 reasons Saudi Arabia will keep oil prices low. [Online]. Available: http://seekingalpha.com/article/3938596

[7] N. Foo, "Falling crude oil prices: The impact on the economy of the Asia-Pacific Region," International Association for Energy Economics.

[8] Saudi-arabias-economy-between-reality-and-the-future. [Online]. Available: http://www.middleeastobserver.org/

[9] NBC News. [Online]. http://www.nbcnews.com/news/investigations/needle-zero-nigerias-ec onomy-tanking-u-s-oil-exports-dry-n256236

[10] R. Arezki and O. Blanchard. (October 2014). Available: http://blog-imfdirect.imf.org/2014/12/22/seven-questions-about-the-re cent-oil-price-slump

[11] D. Norman and A. Richards, "Modelling Inflation in Australia," RBA-Research Discussion, 2010.

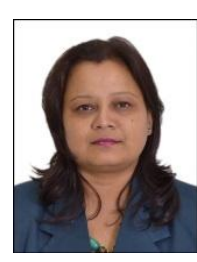

Indrani Hazarika is a business faculty at Dubai Women's College and Chair of Accounting Curriculum at Higher colleges of Technology. She is a gold medalist from Guwahati University for being the University topper in master degree and was awarded the prestigious Junior Research Fellowship by University Grants Commission of India. She is a member of the Institute of Chartered Accountants of India and had obtained her $\mathrm{PhD}$ in the area of direct tax. She is also certified in IFRS from ICAI and SAP Certified Associate in Business Process Integration. She is a member of the review board of International Business Information Management Association and Asia Pacific Studies Journal. Having a passion for research and learning she has joined academics. She has published research papers at leading journals and to name a few: International Journal of Trade, Economics and Finance, Journal of Energy and Economic Development, Joint publication in the Journal of Indian Institute of Labour Economics, Joint publication in the Conference Proceedings of Academy of World Business, Marketing and Management Development. 